УДК 639.21-027.33:66.01-911.48

DOI https://doi.org/10.15673/swonaft.v84i2.1889

\title{
ВИКОРИСТАННЯ ВТОРИННИХ РИБНИХ РЕСУРСІВ 3 РИБ ВНУТРІШНІХ ВОДОЙМ ПРИ РОЗРОБЦІ ТЕХНОЛОГІЇ ГЕЛЕПОДІБНИХ ЗАЛИВОК
}

Кушніренко Н.М., канд. техн. наук, доцент, Паламарчук А.С., канд. техн. наук, доцент, Патюков С.Д. канд. техн. наук, доцент, Глушков О.А., канд. техн. наук, доцент Одеська національна академія харчових технологій, м. Одеса

Copyring (C) 2020 by author and the journal «Scientific Works»

This work is licensed under Vthe Creative Commons Attribution International License (CC By). http://creativecommons.org/licenses/by/4.0

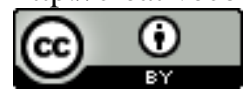

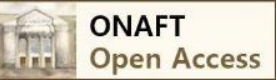

Анотація. Проблема збереження здоров'я населення Украӥни в даний час тісно пов'язана з необхідністю виробництва та наукового обгрунтування розробки повноцінних харчових продуктів загального та спеціального призначення, тому особлива увага приділяється розробиі $i$ впровадженню технологій продуктів харчування, щзо відрізняються високою якістю, безпекою на основі комплексного використання рибної сировини.

Вітчизняні вчені сформулювали теоретичні основи ресурсозберігаючих технологій з урахуванням основних принцииів функціонального харчування. Одним 3 актуальних напрямків у иій галузі $\epsilon$ удосконалення та розробка технологій продуктів харчування масового споживання, особливе місие серед яких займають консерви.

У зв'язку з ичим зберігається тенденція збільшення обсягу виробництва консервів в заливках, також $\epsilon$ важливим розширення їх асортименту, підвищення харчової та біологічної иінності, створення технологій $i$ рецептур багатокомпонентних продуктів. Комбінуючи білки гідробіонтів 3 легкозасвоюваними вуглеводами, вітамінами і мінеральними речовинами овочів можна отримати вироби збалансованого складу, щзо забезпечують вимоги функиіонального харчування людей.

В останні роки увага приділяється збільшенню частки споживання колагенвмісних продуктів, щзо пов'язано із загостренням у людей ряду захворювань опорно-рухового апарату, шлунково-кишкового тракту, тощчо.

Раціональне поєднання різних видів колагену яке міститься в сировині, залучення в виробництво ресурсів, які не використовуються, дозволяе підвищити харчову иінність продуктів, щзо представляе великий інтерес для наукових досліджень і практичної діяльності промислових підприємств.

Споживання в їжу нових видів продуктів, які містять високу кількість сполучнотканинних білків, може спонукати до вирімення проблеми забезпечення населення продуктами харчування, які мають в своєму складі харчові волокна і біологічно активні добавки хондропротекторного типу.

Ключові слова: гелеподібні заливки, колагенвмісні відходи, рибна сировина, рибні бульйони.

\section{THE USE OF SECONDARY FISH RESOURCES FROM INLAND FISH IN THE DEVELOPMENT OF GEL-LIKE FILLINGS TECHNOLOGY}

\author{
N. Kushnirenko, Ph.D., Associate Professor, A. Palamarchuk, Ph.D., Associate Professor, \\ S. Patukov, Ph.D., Associate Professor, O. Glushkov, Ph.D., Associate Professor, \\ Odessa National Academy of Food Technologies, Odesa
}

\begin{abstract}
The problem of preserving the health of the population of Ukraine is currently closely related to the need for production and scientific justification for the development of well balanced foods for general and special purposes, so special attention is paid to the development and implementation of food technologies of high quality, safety based on complex use of fish raw materials.

Domestic scientists have formulated the theoretical foundations of resource-saving technologies, taking into account the basic principles of functional nutrition. One of the current topics in this area is the improvement and development of consumer food technology, a special place among which is canned food.
\end{abstract}


In this regard, there is a tendency to increase the production of canned food in gel-like fillings, it is also important to expand their range, increase nutritional and biological value, create technologies and recipes for products that meet the requirements of functional nutrition.

In recent years, attention has been paid to increasing the share of consumption of collagen-containing products, which is associated with exacerbation of a number of diseases of the musculoskeletal system, gastrointestinal tract and others. Because collagen is poorly digested by human digestive tract enzymes, it can be classified as dietary fiber.

The rational combination of different types of collagen contained in raw materials, the involvement in the production of resources that are not used, can increase the nutritional value of products, which is of great interest for research and practical activities of industrial enterprises.

Consumption of new types of foods that contain high amounts of connective tissue proteins will help solve the problem of providing the population with foods that contain dietary fiber and dietary supplements of the chondroprotective type.

The influence of the species of fish, body parts of fish, technological parameters on the qualitative indicators of gel-like filling for canned fish is investigated in the work.

Keywords: gel-like fillings, collagen-containing waste, fish raw materials, fish broths.

Вступ. У світовій практиці за останній час відбувається зміна структури асортименту консервів 3 гідробіонтів: знижується випуск консервів в маслі і збільшується виробництво консервів з більш складними заливками типу соусів, желе, кремів. Заливки, особливо в поєднанні з овочевими гарнірами, покращують зовнішній вид, створюють комплекс смакових і ароматичних відчуттів, надають консервам апетитного вигляду, сприяють кращому засвоєнню продукту.

Обробка риби і морепродуктів неминуче пов'язана з утворенням відходів. Кількість відходів рибної сировини може досягати $40 \%$ від маси обробленої риби. Світові обсяги не використовуваних рибних ресурсів за даними ФАО складають від 5 до 20 млн. т. / рік [1]. Сировина водного походження становить значний інтерес у зв'язку з вмістом великої кількості в ній колагену.

Роль сполучно-тканинного білка колагену в харчуванні останнім часом переглянута. Він погано піддається дії травних ферментів та за фізіологічним ефектом його також можна перерозглядати, як складову дієтичних волокон, які є незамінним компонентом харчування людини [2].

Колаген у харчовій промисловості може виступати в ролі структуроутворювача. Структуроутворювачі можуть бути натуральними (смоли рослин, камеді вівса і ячменю, крохмалі, карагенан, агар-агар, агароїди, пектини, ізольовані рослинні білки), біосинтетичними (декстрини, ксантан), полусинтетичними (похідні целюлози, крохмалю, хітину, альгінатів) і синтетичними (полівінілхлорид) [3]. Постійно зростаючий асортимент структуроутворювачів розширює можливості в області створення нових продуктів харчування і вдосконалення традиційних технологій виробництва. Сучасні тенденції розвитку вітчизняної і зарубіжної технології та вимоги, що пред'являються до продуктів здорового харчування, свідчать про зростаючу роль натуральних структуроутворювачів для створення харчових продуктів нового покоління. Використання природних компонентів у порівнянні 3 синтетичними має переваги, серед яких основними $є$ наявність лікувальних властивостей.

Перспективним джерелом з'єднувального білка - колагену є вторинні рибні ресурси (шкірний покрив, скелет, плавнці і луска риб) [4]. Технологія отримання чистих структуроутворювачів 3 них досить складна, занадто дорога, екологічно небезпечна. Раціональне використання вторинних рибних ресурсів традиційними технологічними методами ускладнено, тому необхідно розробляти i впроваджувати в переробні галузі нові раціональні і ефективні напрямки обробки сировини на основі комплексної безвідходної та ресурсозберігаючої технології з урахуванням використання всіх побічних продуктів.

В ході аналізу літературних даних встановлено, що використання рибних ресурсів вітчизняні та зарубіжні дослідники приділяють велику увагу. В останні годи отримали розвиток роботи по впровадженню у виробництво колагенвмісних відходів від морських і океанічних риб і виробництва на їх основі рибного желатина, емульсійних продуктів. Однак питання використання рибних відходів від переробки риб внутрішніх водойм для отримання консервів в гелеподібних зливках залишається слабо вивченим. Високу актуальність має створення багатокомпонентних консервів, які завдяки наявності в складі фізіологічно активних природних інгредієнтів, заповнюють дефіцит ессенціальних харчових речовин і надають біологічно позитивний вплив на організм людини. Споживання в їжу нових видів консервів, що містять колаген, може сприяти вирішенню проблеми забезпечення населення продуктами харчування, які мають в своєму складі харчові волокна і біологічно активні добавки хондропротекторної типу. 
Мета і задачі досліджень. Метою роботи є обгрунтування та розробка технологій гелеподібних заливок з колагенвмісних рибних відходів.

Для досягнення поставленої мети необхідно вирішити наступні задачі:

- визначити вміст білка колагену в різних органах і тканинах риб;

- дослідити вплив різних видів риб, різних частин тіла, технологічних факторів (ступеня подрібнення, гідромодуля, температури, тривалості теплової обробки, $\mathrm{pH})$ на властивості бульйонів утворювати желеподібну структуру;

- розробити технологію, визначити органолептичні, фізико-хімічні, реологічні характеристики заливок на основі колагеновмісних вторинних рибних ресурсів.

Матеріали і методи досліджень. Об'єктами дослідження були частини тіла (голова, хребтова кістка, плавці, шкіра, луска) товстолобика білого (Hypophthalmichthys molitrix) та річкового окуня (Perca fluviatilis) в охолодженому і замороженому вигляді; різні види бульйонів, отримані з окремих частин тіла риб і їх сумішей; гелеподібні заливки на основі колагенвмісних вторинних рибних ресурсів.

Для отримання інформації про склад та властивості об'єктів дослідження використовувалися загальноприйняті методи дослідження:

- кількість білка за загальним азоту методом Кьельдаля;

- визначення фракційного складу білка - методом Осборна;

- масову частку колагену визначали за методом Воловінскої В.П.

- кінематичну в'язкість бульйонів - за допомогою віскозіметра капілярного скляного типу ВПЖ-2 (Оствальда) з внутрішнім діаметром капіляра 2,4 мм.

- масову частку розчинних сухих речовин рибних бульйонах і зливках проводили за допомогою рефрактометра ІРФ-2.

- $\quad$ концентрація водневих іонів $(\mathrm{pH})$ потенціометричним методом на $\mathrm{pH}$-метрі типу $\mathrm{pH}-150$;

- для визначення ефективної в'язкості рибних бульйонів використовували ротаційний віскозиметр «Reotest-2» (Німеччина).

Результати досліджень. Видовий склад рибної сировини, яка переробляється в Україні відзначається різноманітністю. Об'єктами переробки в даний час окрім морських і океанічних риб стають такі риби, як судак, товстолобик, окунь річковий, щука, короп та інші, які направляють на виробництво консервів, баличних виробів або реалізують населенню в обробленому вигляді. 3 точки зору комплексного використання сировини ці риби повністю не вивчені.

Можливі обсяги сировини для виробництва заливок, які можна одержати при переробці риб, можна оцінити виходячи 3 масового складу тіла риб. Визначено масовий склад риб товстолоб білий (Нуроphthalmichthys molitrix) та окунь річковий (Perca fluviatilis), отримані результати порівнювали з літературними даними [5].

Кількість отриманих відходів від розбирання досліджуваних риб коливається в межах:

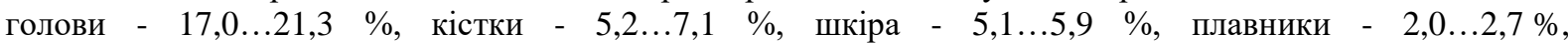
луска - 2,1 ...,0 \%. Загальна частка рибних колагенвмісних відходів сягає $33,8 \ldots 37,5 \%$.

Досить високий обсяг колагенвмісних відходів від розбирання риб припускає доцільність їх використання для виробництва різноманітних продуктів харчування, в тому числі і заливок. Основним білком сировини, що обумовлює його здатність утворювати структуру гелю, є колаген, в зв'язку з цим визначили кількість білка і колагену в частинах риб.

Результати дослідження масової частки загального білка і колагену у відходах риб на прикладі відходів - голови, хребтової кістки, плавців, шкіри, луски товстолобика білого і окуня показали, що частка білкових сполук коливається в залежності від виду риб і частин тіла (табл. 1).

Таблиця1 - Вміст загального білка і колагену в різних частинах риб

\begin{tabular}{|c|c|c|c|c|c|c|c|c|c|c|}
\hline \multirow{3}{*}{ Вид риби } & \multicolumn{10}{|c|}{ Масова частка, $\%$} \\
\hline & \multicolumn{2}{|c|}{ Голова } & \multicolumn{2}{|c|}{ Хребтова кістка } & \multicolumn{2}{|c|}{ Плавці } & \multicolumn{2}{|c|}{ Шкіра } & \multicolumn{2}{|c|}{ Луска } \\
\hline & Білок & Колаген & Білок & Колаген & Білок & Колаген & Білок & Колаген & Білок & Колаген \\
\hline $\begin{array}{l}\text { Товстолобик } \\
\text { білий }\end{array}$ & 14,35 & 9,86 & 15,37 & 11,53 & 17,90 & 13,60 & 32,40 & 29,41 & 34,09 & 28,75 \\
\hline Окунь & 15,87 & 11,37 & 17,06 & 13,13 & 19,0 & 14,82 & 28,25 & 24,86 & $32,04 \pm$ & 25,63 \\
\hline
\end{tabular}

Встановлено, що на частку колагену в головах досліджуваних риб доводиться від 68 до71 \% всіх білкових речовин, в кістках від 75 до 76 \%, плавниках від 75 до 78 \%, шкірі від 85 до 93\%, лусці від 80 до $84 \%$. Вивчені риби за вмістом колагену у відходах відрізняються від морських риб. 
Роботи вчених щодо виділення колагену з океанічних і морських риб показали, що його вміст варіюється від 3,8 до 20,0\% [6]. У минтаю вміст колагену коливається в наступних межах: кістки - 7,63 ..8,49\%, плавці - 9,49...10,82\%, шкіра $-19,70 \ldots 20,09 \%$.

Проведеними роботами встановлено, що частини товстолобика та окуня містять колагену на 23...32 \% більше, ніж у відходах морських і океанічних риб.

Виявлене розходження в отриманні білкових компонентів в досліджуваних прісноводних, морських і океанічних риб можна пояснити різною місцем існування.

За масовою часткою колагену в частинах тіла їх можна розташувати в порядку спадання в наступному порядку: луска > шкіра > плавці > кістки > голова.

Виявлений досить високий рівень вмісту колагену у вторинних рибних ресурсах підтверджує можливість використання їх для створення гелеподібних заливок.

Результати дослідження мінерального складу різних частин тіла риб на прикладі голови, хребтової кістки, плавців товстолобика показав, що частка кальцію, фосфору, заліза, цинку, марганцю, міді коливається в залежності від частини тіла (табл. 2).

Таблиця 2 - Мінеральний склад частин тіла товстолобика

\begin{tabular}{|c|c|c|c|}
\hline \multirow{2}{*}{ Найменування показників } & \multicolumn{3}{|c|}{ Вміст в сухій речовині } \\
\hline & Голова & Хребтова кістка & Плавці \\
\hline Макроелементи г/кг: & & & \\
\hline Кальцій & 164,0 & 143,5 & 139,5 \\
\hline Фосфор & 58,0 & 49,8 & 53,20 \\
\hline Мікроелементи, мг/кг: & & & \\
\hline Залізо & 181,1 & 174,1 & 155,8 \\
\hline Цинк & 82,9 & 65,6 & 118,6 \\
\hline Марганець & 15,7 & 11,9 & 19,1 \\
\hline Мідь & 2,8 & 1,6 & 3,10 \\
\hline
\end{tabular}

Найбільший вміст кальцію і фосфору зосереджені в голові товстолобика. Плавці більше ніж інші частини тіла містять цинку, марганцю і міді. У хребтовій кістці з мікроелементів переважає залізо, на другому місці - цинк.

Експериментальні роботи показали, що прісноводні риби водойм України за обсягами переробки, виходу частин тіла, кількості колагену можуть бути джерелом отримання гелеподібних заливок при виробництві консервів. Встановлений кількісний вміст кальцію, фосфору, заліза, цинку, марганцю, міді дозволяє збагатити готовий продукт важливими для обміну організму людини елементами. Аналіз літературних даних свідчить про те, що при виробництві консервів типу «Юшка», «Риба в желе», «Риба в бульйонах і різних соусах» використовують бульйони як заливки з додаванням структуроутворювачі або без них [7].

Технологія отримання заливок заснована на тривалій термічній обробці неподрібнених частин тіла риб [8]. Недоліком такої обробки є недостатня підготовка сировини, жорстка тривала термічна обробка сировини, що призводить до погіршення органолептичних властивостей і зниження харчової цінності продуктів. Для отримання необхідних структурних властивостей в бульйони вводять додатково речовини, що володіють структуротворними властивостями, переважно желатин, агар або агароїд, карагенан. Полісахариди рослинного походження (агар-агар, агароїди, карагенан) мають високі якісні характеристики, але дорогі. Обсяги виробництва желатину скорочуються у зв'язку з рядом причин (зменшення продукції тваринництва, захворювання тварин і т.д.).

Технології отримання натуральних структуроутворювачів тваринного походження засновані на кислотному, лужному, ферментативних гідролізах сировини або на використанні теплового впливу на колагенвмісну сировину. Кожен із застосовуваних способів має ряд недоліків [9, 10].

Для отримання гелеподібних заливок з відходами в риб нами обрана теплова обробка частин тіла риб при певному $\mathrm{pH}$ середовищі. Вплив різних факторів на структуроутворюючу здатність бульйонів 3 колагенвмісних відходів риб оцінювали за величиною кінематичної в'язкості і змістом сухих речовин, які впливає на в'язкість бульйону. Вплив виду риб на перехід сухих речовин у бульйон і його кінематичну в'язкість оцінювали при тепловій обробці голів товстолобика і окуня річкового (температура $100{ }^{\circ} \mathrm{C}$ час 40 хвилин, гідромодуль 1).

Результати досліджень показали, що при однакових умовах обробки кінематична в'язкість і масова частка сухих речовин вище в бульйонах з голів товстолобика в порівнянні з бульйоном з голів окуня річкового. Так в'язкість бульйонів 3 голів товстолобика - 6,02 $\mathrm{mм}^{2} / \mathrm{c}$, окуня річкового - 4,66 $\mathrm{мm}^{2} / \mathrm{c}$, що 
обумовлено різним вмістом в них білкових сполук, кількість сухих речовин, які перейшли в бульйони, склала відповідно 4,6 та 3,8 \%.

Відзначено, що бульйони 3 голів окуню володіють найкращими органолептичними показниками. Бульйони 3 голів товстолоба містить велику кількість пігментів - міцинів. Наявність міцинів обумовлює їх більш темний колір і підвищену каламутність.

Частини тіла товстолобика при однакових режимах обробки більшою мірою здатні до переходу в бульйон структуроутворюючих сполук, ніж частини окуню (табл. 3).

Таблиця 3 - Залежність характеристик бульйонів від виду частин риб

\begin{tabular}{|l|c|c|c|c|}
\hline \multirow{2}{*}{$\begin{array}{c}\text { Частини } \\
\text { тіла }\end{array}$} & \multicolumn{2}{|c|}{ Товстолобик } & \multicolumn{2}{c|}{ Окунь } \\
\cline { 2 - 5 } & $\begin{array}{c}\text { Масова частка } \\
\text { сухих речовин, } \%\end{array}$ & $\begin{array}{c}\text { Кінематична в'язкіс } \\
\text { ть, мм / с }\end{array}$ & $\begin{array}{c}\text { Масова частка } \\
\text { сухих речовин, } \%\end{array}$ & Кінематична в'язкість, мм / с \\
\hline кістки & $3,8+0,3$ & $4,01+0,13$ & $3,6+0,3$ & $3,89+0,08$ \\
голова & $4,4 \pm 0,3$ & $6,02+0,16$ & $3,8 \pm 0,4$ & $4,66+0,10$ \\
Плавці & $5,9 \pm 0,4$ & $7,71+0,18$ & $4,8 \pm 0,3$ & $7,29+0,13$ \\
шкіра & $11,0 \pm 0,3$ & $10,5410,13$ & $7,9 \pm 0,2$ & $8,31+0,10$ \\
луска & $15,0 \pm 0,2$ & $22,52 \pm 0,10$ & $9,7 \pm 0,2$ & $11,20+0,2$ \\
\hline
\end{tabular}

Дані експериментальних робіт показали, що бульйони, отримані з різних вторинних сировинних ресурсів риб, володіють різною структуроутворюючою здатністю.

Експериментальні дані свідчать про те, що бульйони з луски в порівнянні з іншими мають найбільш високу кінематичну в'язкістю, містять більш значну кількість сухих речовин.

За характером бульйони, отримані з різних частин тіла риб можна розташувати в порядку убування в наступний ряд: луска> шкіра> плавники> голова> кістки

Наведений ряд показників бульйонів співвідноситься 3 масовою часткою колагену в різних частинах тіла риб.

3 метою вибору умов низькотемпературного зберігання рибних відходів вивчені якісні характеристики бульйонів, отриманих з охолоджених і морожених голів різних термінів зберігання.

Оцінку впливу способу і строків зберігання на кінематичну в'язкість і масову частку сухих речовин визначали при отриманні бульйонів при температурі обробки $100{ }^{\circ} \mathrm{C}$, гідромодуль 0,5 і тривалості теплової обробки в інтервалі 20..120 хвилин. Отримані дані виявили залежності кінематичної в'язкості і масової частки сухих речовин бульйонів від тривалості термічної обробки, а також від способу низькотемпературного зберігання та термінів зберігання морожених голів.

Показники якості бульйонів залежать, в першу чергу, від тривалості теплової обробки. Збільшення часу нагріву з 10 до 120 хвилин призвело до підвищення в'язкості бульйонів з охолоджених і морожених голів в залежності від термінів зберігання від 1,6 до 1,8 рази. Масова частка сухих речовин зростала на $40 . .50 \%$.

Максимальна в'язкість розчинів, отриманих 3 морожених голів після 4 місяців зберігання при температурі мінус $18 \mathrm{C}^{\mathrm{o}}$, в більш ніж 1,3 рази нижче в'язкості зразків бульйонів з охолодженої сировини. В'язкість бульйонів,отриманих 3 морожених голів, що зберігалися протягом 1 місяця, змінилася на $10 \ldots 11 \%$, в порівнянні 3 охолодженою сировиною. Застосування тривалих негативних температур для зберігання відходів уповільнює, але не зупиняє процеси, що призводять до зниження якісних показників вихідної сировини. В процесі тривалого зберігання протікають гідролітичні і окиснювальні зміни ліпідів, які стимулюються дією ліполітичних ферментів, що призводить до появи в бульйонах, отриманих з сировини, яка зберігалася більше 4 місяців, неприємних ознак смаку і запаху окисленого жиру. Продукти гідролізу ліпідів утворюють з білком нерозчинні комплекси, що знижують розчинність білка, що позначається на структуроутворюючої здатності рибних бульйонів.

Таким чином, встановлено, що вторинні рибні ресурси для подальшого виробництва заливок слід зберігати в охолодженому стані протягом часу встановленого нормативними документами. Термін зберігання замороженої сировини для отримання заливок високої якості повинен бути не більше 4 місяців. Збільшенню виходу сухих речовин, поліпшенню структур і отримання гелю сприяє подрібнення рибних відходів. Критерієм оцінки якості бульйону служить кількість сухих речовин і величина кінематичної в'язкості. Вплив ступеня подрібнення сировини на характеристики бульйонів вивчали при обробці голів риби (температура $100{ }^{\circ} \mathrm{C}$, гідромодуль 1, час обробки від 20 до 60 хвилин). Голови подрібнювали до стану фаршу (діаметр 3,0 мм), частинок масою 5..15 грам і 20..25 грам.

Термічна обробка сировини, подрібненої до стану фаршу, дозволяє отримати бульйони 3 великим вмістом сухих речовин $(6,4 \%)$ і високою кінематичною в'язкістю $\left(9,8 \mathrm{~mm}^{2} / \mathrm{c}\right)$ при часу теплової обробки 60 хвилин, а, отже, і з більш міцним холодцем. Однакові значення масової частки сухих речовин i 
в'язкості бульйонів отримується при термічній обробці голів риби масою $20 \ldots 25$ г. протягом 40 хвилин, і масою 5..15 м-20 хвилин, тобто тривалість варки при подрібненні відходів на шматочки $5 \ldots 15$ м скорочується в 2 рази. Для визначення впливу гідромодуля на масову частку сухих речовин бульйонів, отриманих при термічної обробки шкури 3 лускою, кісток і плавців товстолоба були обрані співвідношення відходи: вода 1:0,5, 1:1, 1:1,5, 1:2 при температурі теплової обробки $100{ }^{\circ} \mathrm{C}$ і тривалості 40 хвилин. 3 даних слід, що раціональним є гідромодуль $0,5 \ldots 1,0$, коли в бульйони переходить найбільша кількість сухих речовин, а заливки, приготовані на таких бульйонах, мають міцну консистенцію. Структуроутворюючі властивості розчинів залежать не тільки від виду риби і типу тканин, гідромодуля, але і від температури термічної обробки відходів. У табл. 4 наведені показники якості бульйонів 3 кісток риби, отриманих при різних температурах, гідромодулю, часу теплової обробки.

Таблиця 4 - Вплив температурної обробки на характеристики бульйонів з морожених кісток толстолобика

\begin{tabular}{|c|c|c|c|c|c|c|}
\hline \multirow{3}{*}{$\begin{array}{l}\text { Час теплової } \\
\text { обробки, хв. }\end{array}$} & \multicolumn{6}{|c|}{ Показники } \\
\hline & \multicolumn{2}{|c|}{$80^{\circ} \mathrm{C}$} & \multicolumn{2}{|c|}{$100^{\circ} \mathrm{C}$} & \multicolumn{2}{|c|}{$120^{\circ} \mathrm{C}$} \\
\hline & $\begin{array}{c}\text { Кінематична } \\
\text { в'язкість, мм²/с }\end{array}$ & $\begin{array}{c}\text { Вміст } \\
\text { сухих } \\
\text { речовин, } \%\end{array}$ & $\begin{array}{c}\text { Кінематична } \\
\text { в'язкість, мм²/с }\end{array}$ & $\begin{array}{c}\text { Вміст } \\
\text { сухих } \\
\text { речовин , } \%\end{array}$ & $\begin{array}{c}\text { Кінематична } \\
\text { в'язкість, мм²/с }\end{array}$ & $\begin{array}{c}\text { Вміст } \\
\text { сухих } \\
\text { речовин, \% }\end{array}$ \\
\hline 20 & 3,65 & 2,8 & 4,63 & 3,5 & 6,4 & 4,4 \\
\hline 30 & 3,88 & 3,0 & 4,88 & 3,8 & 5,2 & 4,1 \\
\hline 40 & 3,96 & 3,4 & 5,40 & 4,2 & 4,45 & 3,6 \\
\hline 60 & 4,20 & 3,8 & 6,70 & 5,4 & 4,14 & 3,2 \\
\hline
\end{tabular}

Як видно з табл. 4, кінематична в'язкість і масова частка сухих речовин в бульйоні зростає зі збільшенням температури обробки від 80 до $100{ }^{\circ} \mathrm{C}$. Бульйони, отримані при температурі $100{ }^{\circ} \mathrm{C} \epsilon$ найбільш в'язкими $\left(4,63 \ldots 6,70\right.$ мм $\left.{ }^{2} / \mathrm{c}\right)$ в порівнянні з тими, які готувалися при температурах $80{ }^{\circ} \mathrm{C}$ i $120{ }^{\circ} \mathrm{C}$. Бульйони, отриманні при $120{ }^{\circ} \mathrm{C}$, виявляють високу каламутність, а гелі на їх основі мають коричневий колір.

Проведені дослідження дозволили визначити склад вторинних рибних ресурсів. Він становить суміш відходів (голова, кістки, плавники, шкура, луска) 3 різними характеристиками до структуроутворення. Показано, що хорошими властивостями володіють бульйони 3 вмістом сухих речовин більш $6 \%$. Важливою характеристикою для гелеподібних структур є консистенція, яка залежить і від масової частки сухих речовин бульйонів. Для оцінки залежності структури гелю від масової частки сухих речовин провели роботи по визначенню ефективної в'язкості гелеподібних бульйонів від швидкості зсуву. Гелеутворююча здатність бульйонів знаходиться в прямій залежності від вмісту в них сухого залишку і білкових речовин. При утриманні в бульйонах сухих речовин 6,0 \% і вище після попереднього охолодження відбувається утворення структурованої колоїдної системи - гелю. Консистенція гідрогелей визначається масовою часткою сухих речовин. Так, гідрогель 3 масовою часткою сухих речовин $3 \%$ після охолодження до температури $5{ }^{\circ} \mathrm{C}$ має структуру гелю, яка швидко руйнується. Гідрогелі 3 концентрацією 6 i $10 \%$ сухих речовин володіють міцною еластичною консистенцією желе, найбільш виражений характер відзначений у $10 \%$-го гідрогелю. Більш концентровані гідрогелі мають високу ефективну в'язкість (рис. 1).

Найбільше значення в'язкості відзначено у гідрогелю 3 концентрацією $10 \%$ (5,67 Па·с). Величина в'язкості для гідрогелю концентрацією 3 \% невелика i складає 3,02 Па·с.

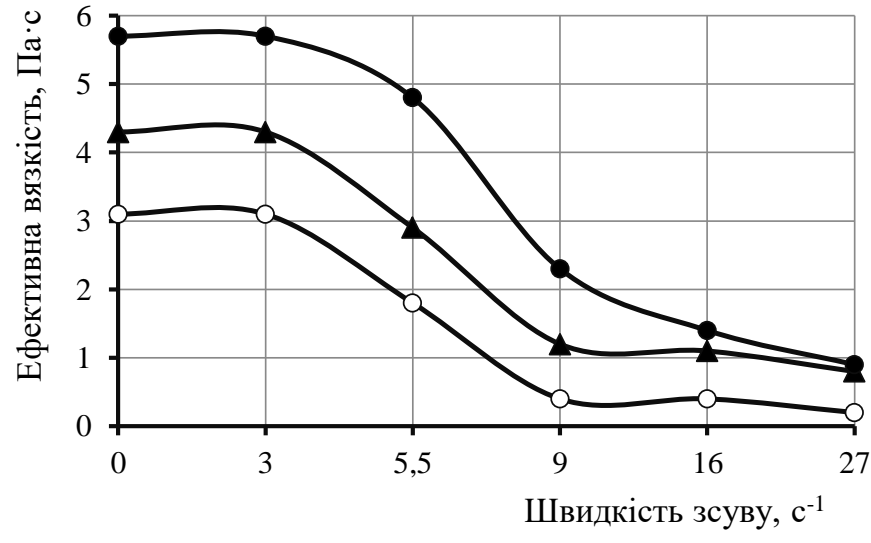

-—масова частка гідрогелю - $10 \%$;
- масова частка гідрогелю - $6 \%$;
$\longrightarrow$-масова частка гідрогелю - $3 \%$

Рис. 1 - Залежність ефективної в'язкості гідрогелів від швидкості зсуву 
3 графічних даних видно, що гідрогелі з вторинних рибних ресурсів є псевдопластичними рідинами 3 плином, який $є$ притаманним для розм'якшення внаслідок руйнування структури зі збільшенням швидкості деформації. Верхня ділянка кривих показує значення ефективної в'язкості в області незруйнованої структури. При збільшенні швидкості зсуву відбувається руйнування просторової структури холодцю, в'язкість різко зменшується [11].

Для отримання рибних бульйонів, які містять не менше 6\% сухих речовин, слід застосовувати термічну обробку при температурі $100{ }^{\circ} \mathrm{C}$ протягом 40 і більше хвилин при гідромодулю $0,5 \ldots 1,0$.

Найважливішим фізико-хімічним параметром, що впливає на перебіг швидкості гідролізу колагену, $\epsilon$ концентрація водневих іонів ( $\mathrm{pH}$ середовища).

Залежність кінематичної в'язкості бульйонів, приготованих 3 кісток риби від рН досліджували в діапазоні $\mathrm{pH}$ середовища від 2,8 до 8 при температурі теплової обробки $100^{\circ} \mathrm{C}$ протягом 40 хв $\mathrm{i}$ гідромодулю 1.

Для створення необхідних значень рН використовували лимонну кислоту. Результати представлені на рис. 2.

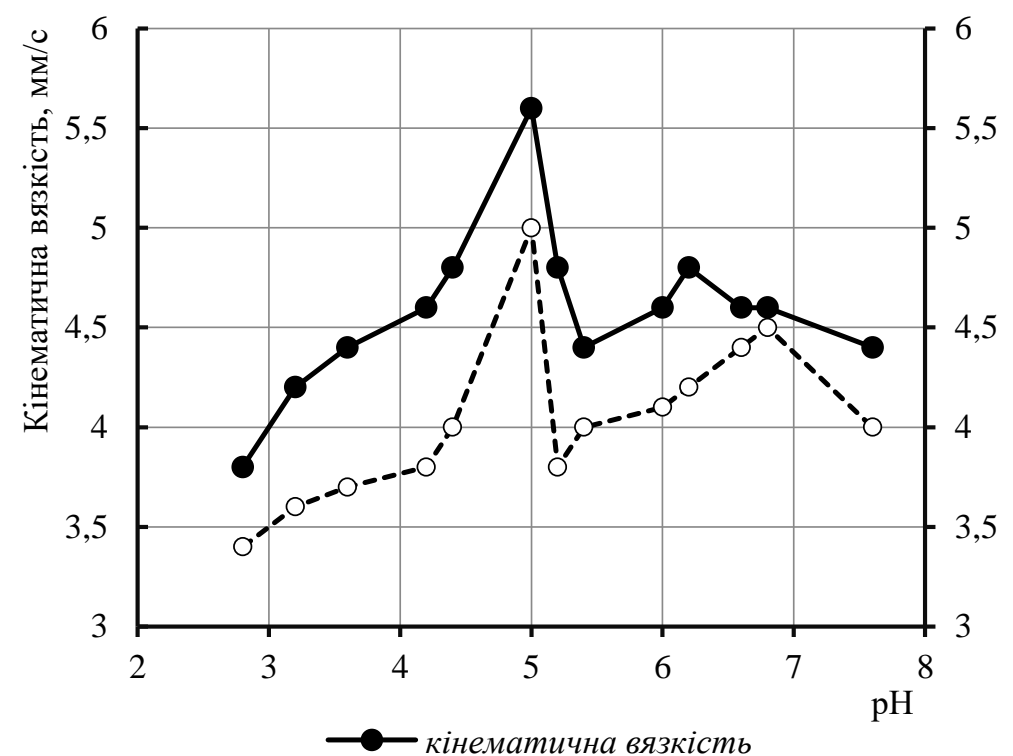

Зміна кінематичної в'язкості і відповідно масової частки сухих речовин мали складну залежність. Як видно з рис. 2, в процесі термічної обробки відбувається зростання масової частки сухих речовин в бульйонах, збільшення кінематичної в'язкості при наступних значеннях $\mathrm{pH}$ рідкої фази: $3,2 \ldots 4,0 ; 4,4 \ldots 5,2 ; 6 \ldots 7,6$, що свідчить про накопичення продуктів гідролізу. Максимум гідролітичного розпаду колагену до желатиноподібних речовин станеться при $\mathrm{pH} 4,8$ i відповідає кінематичної в'язкості $5,58 \mathrm{mм} / \mathrm{c}$ і масовій частці сухих речовин $5,1 \%$.

$$
\text { Для отримання }
$$

Рис. 2 - Зміни кінематичної в'язкості та вмісту сухих речовин бульйонів від рН середовища високонцентрованих бульйонів, що володіють високими структуроутворюючими властивостями, слід використовувати рибні тканини з високим вмістом колагену або суміш тканин.

При виборі вибору складу готували бульйони з різним поєднанням тканин (тривалість обробки 40...60 хвилин, температура $100{ }^{\circ} \mathrm{C}$, гідромодуль 1). Результати досліджень зображені в табл. 5.

Таблиця 5 - Характеристика варіантів, використовуваних при отриманні бульйонів 3 відходів

\begin{tabular}{|c|c|c|c|c|}
\hline \begin{tabular}{|c|c|} 
№ \\
варіанту
\end{tabular} & Склад компонентів & $\begin{array}{l}\text { Час теплової } \\
\text { обробки, хв. }\end{array}$ & $\begin{array}{c}\text { Кінематична в'язкість, } \\
\text { м }^{2} / \mathrm{c}\end{array}$ & $\begin{array}{c}\text { Масова частка сухих } \\
\text { речовин, \% }\end{array}$ \\
\hline 1 & 2 & 3 & 4 & 5 \\
\hline \multirow{2}{*}{1} & \multirow{2}{*}{ Голова, шкіра, луска } & 40 & 6,71 & 7,80 \\
\hline & & 60 & 7,56 & 8,60 \\
\hline \multirow{2}{*}{2} & \multirow{2}{*}{ Голова, кістки, плавці } & 40 & 4,95 & 5,70 \\
\hline & & 60 & 5,56 & 6,40 \\
\hline \multirow{2}{*}{3} & \multirow{2}{*}{ Кістки, плавці } & 40 & 4,38 & 5,40 \\
\hline & & 60 & 5,34 & 6,20 \\
\hline \multirow{2}{*}{4} & \multirow{4}{*}{$\begin{array}{c}\text { Кістки, плавці, шкіра з лускою } \\
\text { Голова, кістки, плавці, шкіра, } \\
\text { луска }\end{array}$} & 40 & 8,14 & 7,00 \\
\hline & & 60 & 10,68 & 8,50 \\
\hline \multirow{2}{*}{5} & & 40 & 12,01 & 8,70 \\
\hline & & 60 & 13,45 & 9,40 \\
\hline
\end{tabular}


Найкращі показники якості мають бульйони при наступному поєднанні тканин риби: голова, кістки, плавники, шкіра, луска. В'язкість бульйонів становить $12,01 \ldots 13,45$ мм/с, масова частка сухих речовин $-8,70 \ldots 9,40 \%$. Використання шкіри 3 лускою при приготуванні бульйонів призводить до багаторазового збільшення його в'язкості і масової частки сухих речовин.

В результаті проведених досліджень встановлено залежність виду і частин тіла риби, способів і термінів зберігання, технологічних параметрів (ступінь подрібнення, тривалість і температура теплової обробки, рН рідкого середовища) і способу зберігання на структуроутворюючу здатність гелеподібних бульйонів.

Висновки.

1. Теоретично обгрунтовано та експериментально підтверджено доцільність використання вторинних рибних ресурсів прісноводних риб для отримання геледібних заливок. Встановлено, що вміст колагену в різних частинах тіла риб коливається від 9,9 до 29,4 \%.

2. Визначено склад вторинних рибних ресурсів, що становить суміш відходів (голова, кістки, плавники, шкура, луска) з різними характеристиками до структуроутворення. Показано, що кращіми властивостями володіють бульйони з вмістом сухих речовин більш $6 \%$.

3. Досліджено вплив виду, частин тіла риби, технологічних чинників (ступінь подрібнення, $\mathrm{pH}$, гідромодуль, температура, тривалість теплової обробки), що визначають інтенсивність процесу гідролізу колагену при тепловій обробці рибних відходів.

4. Встановлені оптимальні параметри (температура $93 \ldots 108{ }^{\circ} \mathrm{C}$, час $50 \ldots 90$ хвилин, $\mathrm{pH} 4,2 \ldots 6,0$ ) способу виробництва гелеподібних заливок, що дозволяє скоротити час технологічного процесу, поліпшити їх реологічні, органолептичні показники, а також підвищити харчову і біологічну цінність готового продукту. Тверду частину сировини після отримання заливок запропоновано направляти на потреби сільського господарства.

\section{References}

1. Antipova, L. V., \& Tolpyigina, I. N. (2011). Rasshirenie assortimenta ryibnyih produktov. Ryibovodstvo $i$ ryibnoe hozyaystvo, (2), 45 - 49.

2. Andrusenko, P. I. (1988). Maloothodnaya i bezothodnaya tehnologiya pri obrabotke ryibyi. M.: Agropromizdat.112 .

3. Batischev, V. V., \& Antipova, L. V. (2002). Pererabotka i proizvodstvo ryibnoy produktsii: sovremennyie problemyi i perspektivyi ih resheniya. Izvestiya vyisshih uchebnyih zavedeniy. Pischevaya tehnologiya, (5-6). 9 - 11.

4. Bogdanov, V.D., \& Safronova T.M. (1989). Tehnologiya sousov na osnove ryibnyih bulonov // Ryibnoe hozyaystvo.(6). 87.

5. Borisochkina L.I. (2000). Novyi vidyi otechestvennoy i zarubezhnoy produktsii iz ryibyi i bespozvonochnyih // Novosti otechestvennoy $i$ zarubezhnoy ryiboobrabotki: Ser. obrabotka ryibyi $i$ moreproduktov, IV (II).- S. 19 - 14.

6. Belinska, S., Orlova, N., \& Krasnoschok, V. (2008). Modelyuvannya retseptur bagatokomponentnih ovochevih napivfabrikativ // Tovari i rinki, (1), 70 - 73. https://doi.org/10.1159/000115649

7. Kiladze, A. B. (2004). Ryibnyie othodyi - tsennoe syire. Ryibnoe hozyaystvo, (3), 32 - 37.

8. Sahnevich V.S, \& Nozhenko A. I. (2002). Razrabotka tehnologii naturalnyih konservov iz prudovyih ryib // Mezhdunar. nauch.-prakt. konf. "Himiya zhivyih soedineniy» Sb. statey, $107-121$.

9. Spirichev, V. B., \& Shatnyuk, L. N. (2000). Obogaschenie pischevyih produktov mikronutrientami: sovremennyie mediko-biologicheskie aspektyi // Pischevaya promyishlennost, 7, 98 - 101.

10. Mogilnyiy, M. P. (2009). Rol funktsionalnyih svoystv belkov v spetsialnyih vidah pitaniya // Izvestiya vyisshih uchebnyih zavedeniy. Pischevaya tehnologiya, (1).

11. Chernega, N. V. (2006). Razrabotka tehnologii mnogokomponentnyih konservov v geleobraznyih zalivkah iz kollagensoderzhaschih ryibnyih resursov // (Doctoral dissertation, Severo-Kavkazskiy gosudarstvennyiy tehnicheskiy universitet).

Cite as

Кушніренко Н.М., Паламарчук А.С., Патюков С.Д, Глушков О.А. Використання вторинних рибних ресурсів з риб внутрішніх водойм при розробці технології гелеподібних заливок // Наук. пр. / Одес. нац. акад. харч. технологій. Одеса, 2020. Т. 84, вип. 2. С. 49 - 56.

Отримано в редакцію 17.07 .2020

Received 17.07.2020

Прийнято до друку $\quad 07.10 .2020$

Approved 07.10.2020 